\title{
Nursing and Biochemistry: An Evaluation Strategy Using a Basic Discipline to Present to Freshman Students Their Future Professional Environment
}

\author{
Maria Lúcia Magalhães Palma ${ }^{1^{*}}$, Ana Caroline Santana ${ }^{{ }^{*} \text {, }}$ \\ Gustavo Henrique Varela Saturnino Alves², Thays Merçon ${ }^{2}$, Helena Carla Castro ${ }^{1,2}$ \\ ${ }^{1}$ Post-Graduation Program in Science and Biotechnology (PPBI), Federal Fluminense University, Niterói, Brazil \\ ${ }^{2}$ Post-Graduation Program in Teaching in Biosciences and Health, Oswaldo Cruz Foundation, Rio de Janeiro, Brazil \\ Email: hcastrorangel@yahoo.com.br
}

How to cite this paper: Palma, M. L. M., Santana, A. C., Alves, G. H. V. S., Merçon, T., \& Castro, H. C. (2018). Nursing and Biochemistry: An Evaluation Strategy Using a Basic Discipline to Present to Freshman Students Their Future Professional Environment. Creative Education, 9, 497-512. https://doi.org/10.4236/ce.2018.93035

Received: September 25, 2017

Accepted: March 26, 2018

Published: March 29, 2018

Copyright () 2018 by authors and Scientific Research Publishing Inc. This work is licensed under the Creative Commons Attribution International License (CC BY 4.0).

http://creativecommons.org/licenses/by/4.0/

\begin{abstract}
Nursing is a career that involves more than taking care of sick patients, especially when working in health institutions (e.g. Clinics and Hospitals). According to the current curriculum guidelines for nurse graduation, it is necessary for this professional to develop different skills to work in several health care environments, including decision-making, communication, leadership, among others. Therefore, our objective was to plan a strategy to approximate Nursing freshmen students to their professional environment already in the very beginning of their graduate course. On that purpose we planned an evaluation strategy for the discipline Biochemistry using an active methodology to simulate a professional experience. Initially the students were divided into pairs, and had to analyze two different professional situations, both using $\mathrm{Bi}$ ochemical concepts. According to our results, as the evaluation strategy was applied, the students showed surprise and curiosity. The analysis of the questionnaire about the strategy revealed that most of the participants enjoyed the activity using positive words. Thus the strategy showed a good acceptance and presented the desired characteristic of correlating Biochemistry, a basic discipline, with the nurse professional skills. This strategy may allow they become more aware of their responsibilities sooner, as it allows using earlier their competence of seeking solutions to solve situations regarding the professional practices using biochemical basic concepts. This experience may improve them to a future better attendance of their patients.
\end{abstract}




\section{Keywords}

Evaluation, Nursing, Biochemistry, Graduation Course, Active Teaching Methodology

\section{Introduction}

Currently the expenses with health are increasing worldwide as the population gets older and lives longer. In this perspective, nurse is an important professional since their work is essential in health institutions (e.g. clinics and hospitals). According to the current curriculum guidelines, this profession demands different knowledge and skills to work in health care, also including decision-making, communication, and leadership profile, among other skills (De Souza et al., 2017, Pasila et al., 2017).

Biochemistry is one of the most important basic disciplines in the formation of Health care professionals, including for nursing. It is a discipline presented in the very beginning of the course in the nurse graduation curricula. Chemical and Biochemical molecules and complex systems (e.g. Amino acid and proteins) are shown as related to the life maintenance because of their role in biological and pathological processes (Gomes \& Rangel, 2006; Garrido et al., 2010).

According to some authors, the content of basic disciplines are not always well presented for health care professionals, as they generally miss the clear relationship with their professional practices (Backes et al., 2010). It's important to notice that the teaching-learning process is complex and subjective, and also directly and/or indirectly related to others crucial factors (e.g. psychological, social, educational and motivational issues). Thus, despite the students are subjected to the same conditions of learning, practice and theoretical lessons, each one will "receive" and understand the information in a very unique way (Costa et al., 2015; Silva et al., 2010; da Silva et al., 2016).

Based on this context, it is necessary to analyze the current teaching methodologies for basic disciplines such as Biochemistry and to design new current didactic proposals/strategies aimed to contextualize the students' future performance. These new strategies may contribute to a better preparation and skills development of these professionals leading to the better attendance of the patients (Amaral, Figueira, \& de Barros, 2006; Iglésias \& Bollela, 2015; Garrido et al., 2010).

The aim of this paper was to propose a simulation strategy to be used in the evaluation process of basic disciplines (e.g. Biochemistry) in order to get freshman nursing students closer to their future professional practice.

\section{Methods}

\subsection{Evaluation Procedures}

The discipline occurred in the first semester of 2016 with 56 freshmen of Bio- 
chemistry class from the Nursing course of a Brazilian Federal University. The strategy involved a simulation that allows a more dynamic evaluation procedure to be used in traditional classes for teaching Biochemistry basic concepts.

\section{Evaluation Strategy First Step: Preparing the Room}

The classes about basic concepts (amino acids, proteins, enzymes, inhibitors) occurred regularly using traditional lecture methods including PowerPoint slides and movies from Youtube. In the evaluation test day, the Professor arrived before the students to organize the classroom space. The chairs were arranged in pairs, as well as the space on the front of the classroom that should be marked as four infirmaries by using four chairs (Figure 1). Meanwhile, the students had to wait outside the classroom, to increase curiosity.

Thus, at the front of the classroom, the professor placed four chairs, each one representing an infirmary (and a pathological situation) (Figure 1). There were several small sheets above each chair (infirmary) containing the same description about a patient history and/or a testimony about his/her clinical situation (Figure 1). Each infirmary represented a similar pathological situation, with difference only in age and/or gender of the patient, but this was not said to the students. Thus, each freshmen pair should "attend" only one patient in each chair-infirmary as there were only four pathological situations, one in each infirmary. The number of pathological cases was not told to the freshmen that will

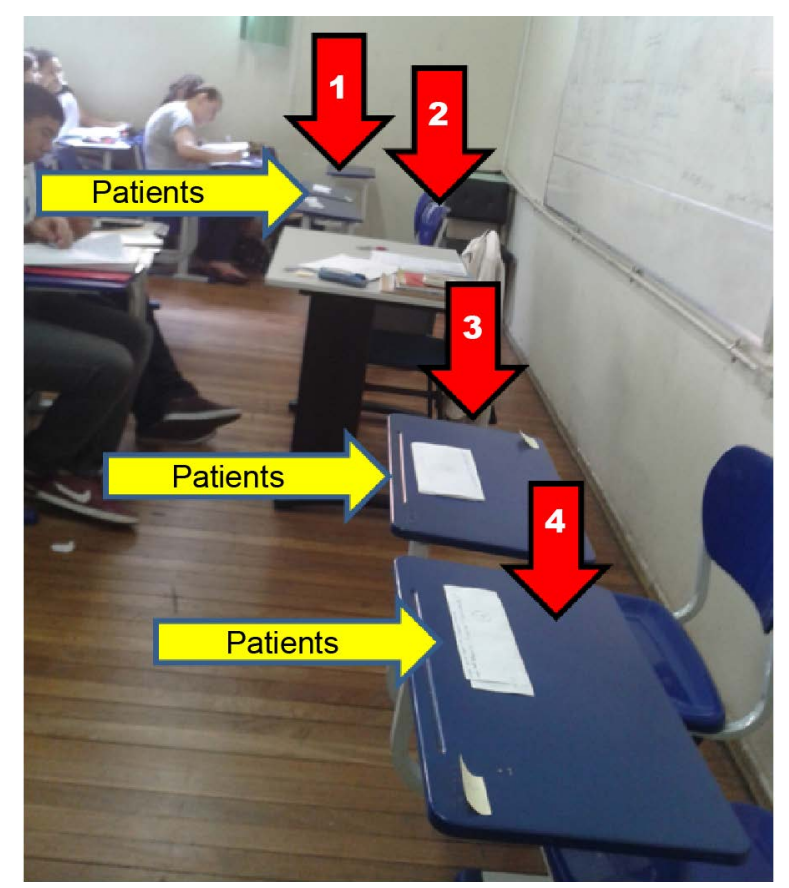

Figure 1. The biochemical evaluation strategy for health professionals tested with Nursing Students from a Brazilian Federal University. The scenario represented by four infirmaries ( 1 - 4 chairs) of the clinic, with the "patients" represented by their histories described on paper sheets placed on the chairs desktop. The freshman students organized in pairs had to attend one patient of each infirmary by describing the relationship among the patient history health conditions, Biochemistry and graphics exams results. 
believe that all patients are different to avoid them to attempt to copy or pay attention other colleagues cases.

After finishing to prepare the classroom, the Professor requested the students to enter and organize them into pairs according to the disposition of the chairs.

Before the activity effectively start, the Professor informed the students that the test was a simulation where the professor represented the director of a Clinic that wants to hire them as a nurse team. Thus, it was expected that all of them demonstrate the capacity and competence on recognizing and treating the clinic patients of these four infirmaries in order to be hired.

The management skills expected in dealing with the four infirmaries were previously discussed with the students. This activity was performed orally when the Professor described some situations with possible solutions relative to the professional daily life. Thus, they reflected and discussed about it before the evaluation and decide if they were in agreement or disagreement about the fact reported, choosing the best solutions. After revealing the answers regarding each situation, the Professor commented the situation and strategies with the students to make them to reflect about the relevance of a good decision-making and teamwork profiles in their future professional life.

\subsection{The Test}

The students were advised that each patient of each infirmary (represented by the sheet placed on the chair) had a clinical situation that should be correlated with known biochemical concepts. The freshmen should use the concepts learnt during the Biochemistry class until that date. The rule was: at least one patient of each infirmary should be attended by at least one pair of freshmen. Thus, in pairs, the students walked towards each chair, took one medical record (sheet), attending a total of four patients, each one from one infirmary. It was allowed to each pair of freshmen to perform the care/analysis of each patient by consulting books, articles and internet through the cell phone.

In the end of this task, it was presented a problematic situation theoretically caused by a nursing assistant that mixed the medical records of the four infirmaries. On that purpose, four graphics were drawn on the board, each one referring to one of these patients (Figure 2).

Thus the freshmen had to analyze, think and help to solve this problematic situation. On that purpose, it was necessary that the students correlated the medical records to the respective infirmary, by using their knowledge on biochemical concepts.

The total time for the whole dynamic evaluation was three hours. After analyzing the whole situation and solving the problem situation, the student had to justify their answers about the relationship between the biochemical data and the patients as well as the final patients' identification. The space to write each response in the test was limited to half sheet.

The verification of the answers was later analyzed by two postgraduate students, guided by the Professor who ministered the activity. 

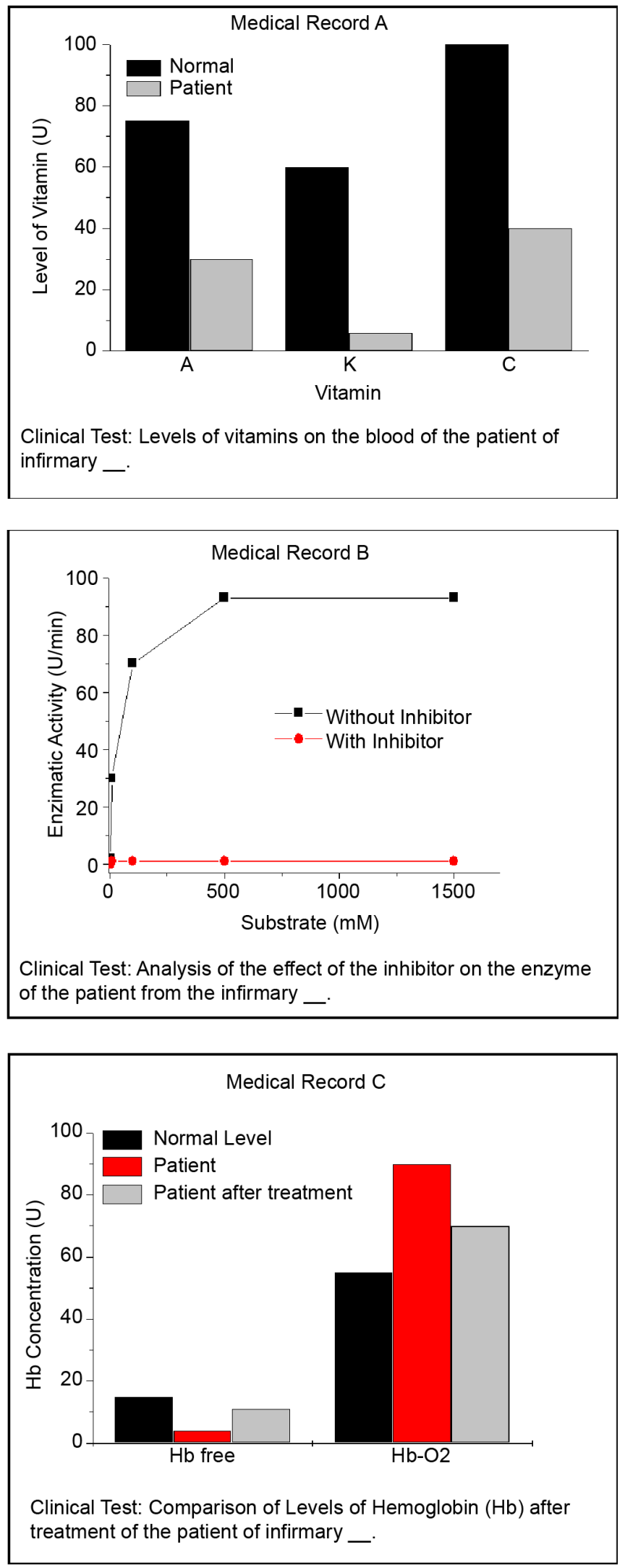

Figure 2. Exams showed to the Nursing freshman students to be correlated with patients symptoms history (see supplementary material). 


\subsection{The Analysis of the Strategy by the Students}

In the following week, the Professor showed the assessments that were fully corrected by the post doctors, and showed their grades. The students $(n=39)$ were invited to answer the questions about the evaluation process, including grade satisfaction (Figure 3).

\section{Results}

According to the freshmen students, they initially received the current evaluation strategy with quite a surprise and curiosity with positive feelings, confirmed by their answers (Figure 4). Most of the participants mentioned words with positive meaning $(\mathrm{n}=30)$ and only four answers were with negative sense. During our analysis, 8 answers were not considered since 2 of them did not mark the sense question (negative or positive), and 6 used positive words as negative or vice versa (Figure 4).
(Assessment 1):
1) I think it was and this opinion has a ( ) positive ( ) negative sense.
2) About the dynamics of the evaluation strategy I found because
3) I think assessments like this one are:
4) As for the assessments style I prefer: (in order of preference):
( )Objective ( )Discursive ( )Mixed ( )The current dynamic approach.
5) I have better grade in ___ evaluation: (in order of success)
( )Objective ( )Discursive ( )Mixed ( )The current dynamic approach.
6) For me, this evaluation has measured:
7) I my grade because

Figure 3. Assessment applied to the Nursing freshman students about their opinions on the new dynamic strategy evaluation procedure.

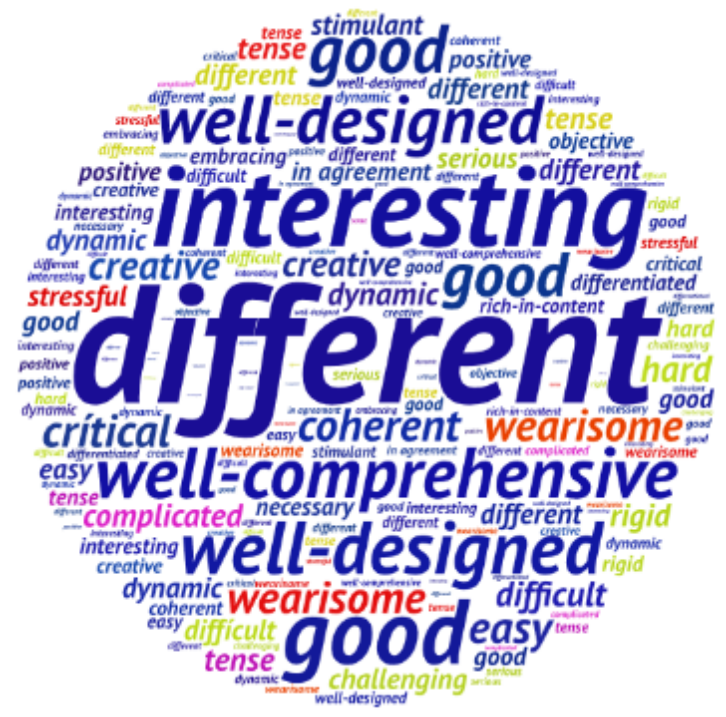

Figure 4. Analysis of the word frequency on answers of the freshmen students of Nursing Graduation Course of a Brazilian Federal University for the question 1) I think it was and this opinion has a ( ) positive ( ) negative sense. The higher case is the most frequent words found in the analysis. 
For analyzing question 2 of the assessment (About the dynamics of the evaluation strategy I found because ), the answers were classified into seven groups, including those related to: a) time; b) professional relationship; c) different approach; d) emotional factors; e) Biochemical contents; f) applied methodology; and others. It was observed that most answers were related to the professional aspects (Graphic 1).

Regarding to their preference about the evaluation style, most of the participants preferred mixed tests, followed by our strategy, despite their inferior performance on tests such as ours (Graphic 2).

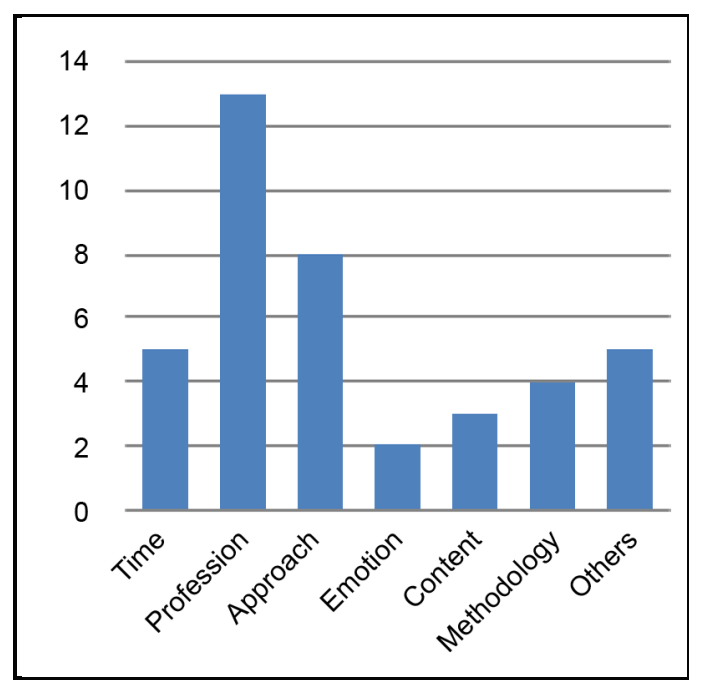

Graphic 1. Classification of the answers from the question number 2 of the freshmen students from Nurse under Graduation course in a Brazilian Federal University about the new evaluation strategy.
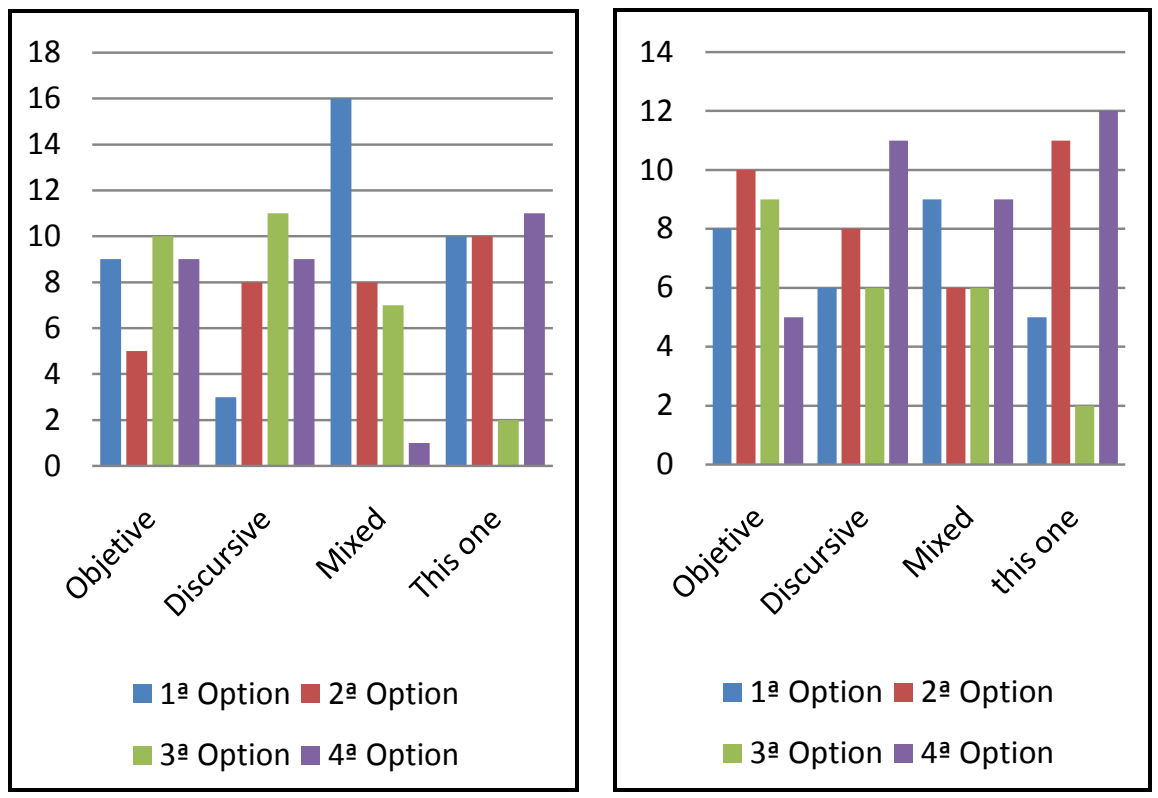

Graphic 2. Comparison of the opinion of the participants regarding their preference in relation to the style and their degree of performance in different evaluation type. 
According to the freshmen, our evaluation was able to measure knowledge. However, no perception that they were also being evaluated on biochemistry contents was significantly cited; Several answers highlighted issues that involve general topics, as described in Table 1.

More than $70 \%$ of the participants were satisfied with their grades considering that they presented positive answers; A participant did not respond because at the time he answered, he still did not know his grade as he did not look at the grade list (Graphic 3).

According to their answers, their grade is a reflection of their effort and time spent to study (positively or negatively) and also the importance attributed to the grade (Table 2).

\section{Discussion}

According to the literature, the current evaluation processes available can be used for different purposes in the professional education, including: a) diagnosis,

Table 1. Answers of the Nursing freshman students about topics related to this type of evaluation (For me, this evaluation has measured: ).

\begin{tabular}{cc}
\hline Topic & Quantity \\
\hline Knowledge & 24 \\
Search/selection of materials & 4 \\
Team work & 19 \\
Reasoning & 17 \\
Emotional /Personal & 10 \\
Acting under pressure & 10 \\
Content & 6 \\
Time control & 10 \\
Theory X Practice & 6 \\
Response Type & 2 \\
Others & 6
\end{tabular}

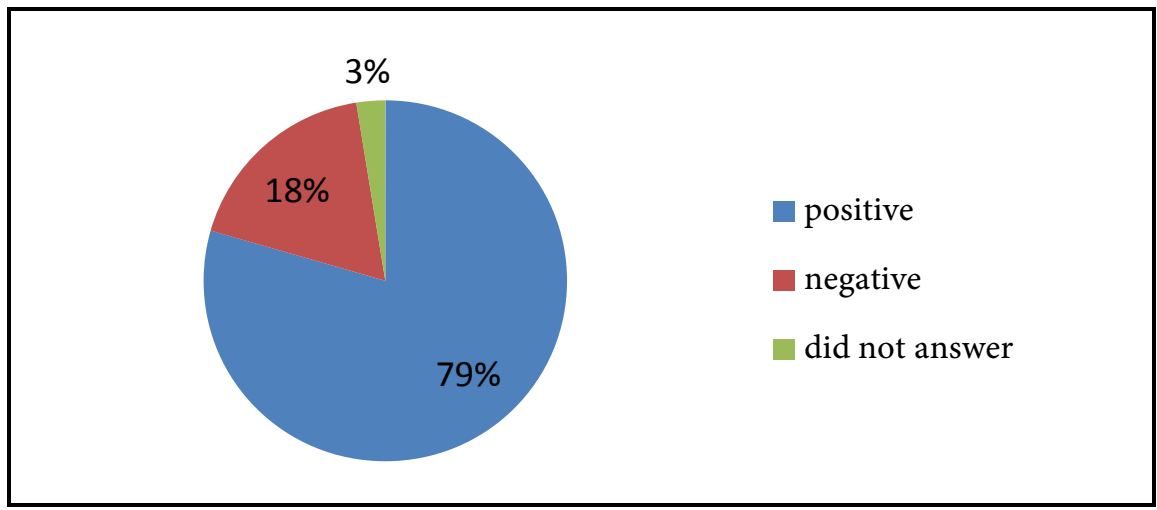

Graphic 3. Freshmen answers about the question "I_ my grade because__". 
Table 2. Factors that interfered with the performance of the freshmen students (grade) according to their opinion.

\begin{tabular}{cc} 
Reason & $\mathbf{n}$ \\
\hline The way the test was applied & 7 \\
Personal /Emotional & 5 \\
Previous Study or Preparation for the test & 17 \\
The grade values & 14 \\
Time of execution & 5 \\
Do it in pair & 3 \\
Theory versus practical approach & 2 \\
\hline
\end{tabular}

in which the error is a constructive factor that lead to the search for alternatives and construction of new knowledge; and b) procedural, occurring throughout the learning process and not only at the end, thus enabling the permanent action-thinking-action of the participants involved. The knowledge evaluation can be quantitative or qualitative and, for example, serve as a basis for verifying the contents that still need to be better addressed (Esteban, 2003; Vasconcelos et al., 2011).

Currently, the undergraduation courses in health area are still in need of new forms of evaluation that help on training and enable the professional to safely carry out their activities. This is especially important when decision-making is decisive for the improvement of patient health, and could save lives or, in certain cases, unfortunately leads to death. The qualification of health care professionals is associated with many factors, especially to the continuous development of comprehensive and important professional behaviors (da Silva et al, 2016).

In this study we created and analyzed a new strategy for evaluating basic concepts of Biochemistry, a discipline of Nursing freshman students. According to some authors, "[...] the great challenge in training nurses is to transpose what is determined (...) training professionals who surpass the theoretical-practical field demanded by the market and become innovative agents and transformers of reality [...]".

One methodology that contributes to the formation of good professionals is the active methodology whose strategy is based on the problematization of real situations. The purpose is, by questioning the students, to allow the use of theoretical acquired foundations and concepts to build and propose new hypotheses to solve the problem presented. On that matter, many courses in the health area are now using problem-based learning (PBL) strategies to teach and stimulate the students to think deeper about their own professional life and situations ahead (Vasconcelos et al., 2011; Carrera et al., 2003, Antepohl \& Herzig, 1999; Barrows, 1985).

PBL has been applied since the 60 's of the 20th century, with the main characteristics of students with formative advances in terms of autonomy and discursive 
articulation for professional practice (Vasconcelos et al., 2011; Antepohl \& Herzig, 1999). Some studies were described included nursing students, revealing the potential of using this approach to make them more aware of their professional challenges (Shin \& Kim, 2013). Importantly, recently evaluation of strategies of active methodologies such as PBL and Team-based learning (TBL), specifically in the nursing course, showed that the practice of these methodologies helps in a more holistic formation developing empathy and of teamwork (Kim et al., 2016; Lee, Nam, \& Kim, 2017).

At present, the literature also described simulation-based education (SBE) that ranges from low to high-fidelity simulation, using realistic clinical scenarios including virtual ones (Kim et al., 2016). This strategy have been helping on formation of several professionals, including nurses but generally on the late years of the course, due to the high cost, specially on non-developed countries.

Herein, we created a strategy that uses PBL and SBE to enroll nursing freshmen students on the perspective of their professional future. The fact that this strategy has been applied to pairs of students can be considered positive because it allows since at the very beginning of the undergraduation course, these students see the importance of hearing each other as well as the need to respect and discuss different ideas. After a debate with plausible arguments, they could reach a decision that is more feasible in the case of each patient as a good exercise for the real life and nurse practical procedures. Currently, this listening activity is still an arduous task, because these individuals are still young and concerned with themselves.

\section{Conclusions}

In this work, we planned a strategy for evaluating nursing professionals on basic disciplines with an applied perspective. It may have an important role on preparing medical professionals as our data showed good acceptance. Thus this strategy may help to stimulate a better and more responsible performance of these professionals in the future.

Overall, it is a methodology that may have the potential to contribute to the formation of professionals aware of their responsibilities, with competence to seek solutions and practices in harmony with their team in order to better serve the patients.

\section{References}

Amaral, C. L. C., Figueira, R. C. L., \& de Barros, M. P. (2006). The Use of Virtual Environments in the Teaching of Biochemistry. A Case Study on UNICSUL. http://bioquimica.org.br/revista/ojs/index.php/REB/article/view/18

Antepohl, W., \& Herzig, S. (1999). Problem-Based Learning versus Lecture-Based Learning in a Course of Basic Pharmacology: A Controlled, Randomized Study. Medical Education, 33, 106-113. https://doi.org/10.1046/j.1365-2923.1999.00289.x

Backes, D. S., Marinho, M., Costenaro, R. S., Nunes, S., \& Rupolo, I. (2010). Rethinking the to be a Nurse Teacher in the Perspective of the Complex Thought. Rev Bras En- 
ferm, 63, 421-426. http://www.scielo.br/pdf/reben/v63n3/a12v63n3.pdf

Barrows, H. (1985) How to Design a Problem-Based Learning Curriculum in the Pre-Clinical Years. New York: Springer-Verlag.

Carrera, L. I., Tellez, T. E., \& D’ottavio, A. E. (2003). Implementing a Problem Based Learning Curriculum in an Argentinean Medical School: Implications for Developing Countries. Academic Medicine, 78, 798-801. https://doi.org/10.1097/00001888-200308000-00010

Costa, M. C. M. D. R., Koerich, C., Ribeiro, J. C., Meirelles, B. H. S., \& Melo, A. L. S. F. (2015). Nursing Care in View of Complex Thinking: Integrative Literature Review. Rev Min Enferm, 19, 180-187. http://pesquisa.bvs.br/brasil/resource/pt/bde-26974

da Silva, L. A. A., Schmidt, S. M. S., Noal, H. C., Signor, E., \& Gomes, I. E. M. (2016). Avaliação da educação permanente no processo de trabalho em saúde. Trabalho, Educação e Saúde, 14, 765-781. https://doi.org/10.1590/1981-7746-sol00015

De Souza, M. C., et al. (2017). The Influence of Nursing in the Development of Popular Education in Health. International Archives of Medicine, 10. http://imedicalsociety.org/ojs/index.php/iam/article/view/2245

Esteban, M. T. (2003). Rating: A Practice in Search of New Directions. Rio de Janeiro: DP\&A.

Garrido, R. G., Araújo, F. O., Oliveira, T. H., \& Garrido, F. S. (2010). The Place of Biochemistry in the Process of Care: Vision of Students in Nursing. Revista de Ensino de Bioquímica, 8, 30-35.

http://sbbq.hospedagemdesites.ws/revista/ojs/index.php/REB/article/view/40/39 https://doi.org/10.16923/reb.v8i1.40

Gomes, K. V. G., \& Rangel, M. (2006). Relevance of Disciplines Biochemist in Different Degree Courses from UESB in Jequié Town.

http://www.uesb.br/revista/rsc/ojs/index.php/rsc/article/viewFile/105/98

Iglésias, A. G., \& Bollela, V. R. (2015). Curriculum Integration: A Challenge for the Undergraduate Courses of the Health Area.

http://revista.fmrp.usp.br/2015/vol48n3/simp8_Integracao-curricular-na-area-da-saud e.pdf

Kim, H. R., Song, Y., Lindquist, R., \& Kang, H. Y. (2016). Effects of Team-Based Learning on Problem-Solving, Knowledge and Clinical Performance of Korean Nursing Students. Nurse Education Today, 38, 115-118. https://doi.org/10.1016/j.nedt.2015.12.003

Kim, J., Park, J. H., \& Shin, S. (2016). Effectiveness of Simulation-Based Nursing Education Depending on Fidelity: A Meta-Analysis. BMC Medical Education, 16, 152. https://doi.org/10.1186/s12909-016-0672-7

Lee, M. N., Nam, K. D., \& Kim, H. Y. (2017). Effects of Simulation with Problem-Based Learning Program on Metacognition, Team Efficacy, and Learning Attitude in Nursing Students: Nursing Care with Increased Intracranial Pressure Patient. CIN: Computers, Informatics, Nursing, 35, 145-151. https://doi.org/10.1097/CIN.0000000000000308

Pasila, K., Elo, S., \& Kääriäinen, M. (2017). Newly Graduated Nurses' Orientation Experiences: A Systematic Review of Qualitative Studies. International Journal of Nursing Studies, 71, 17-27. https://doi.org/10.1016/j.ijnurstu.2017.02.021

Shin, I.-S., \& Kim, J.-H. (2013). The Effect of Problem-Based Learning in Nursing Education: A Meta-Analysis. Advances in Health Science Education, 18, 1103-1120. https://doi.org/10.1007/s10459-012-9436-2

Silva, A. L., \& Freitas, M. G. (2010). Teaching Care in Nursing Graduation According to the Perspective of Complexity. Rev Esc Enferm USP, 44, 687-693. 
http://www.scielo.br/pdf/reeusp/v44n3/en_19.pdf

Vasconcelos, C. M. C. B., Backes, V. M. S., \& Gue, J. M. (2011). Undergraduate Education Evaluation in Nursing in Latin America: An Integrative Review. Revista Electrónica Trimestral de Enfermería, July 2011, 118-139

http://revistas.um.es/eglobal/article/viewFile/131421/121871 


\section{Supplementary Material}

\section{Patients from Infirmary 1}

I am a retired doctor and professor of medicine and I have Alzheimer disease. Today, knowing that I have the disease, I was able to determine when it started 10 years ago when I was 76 years old. I started forging names, but never physiognomy. These lapses are common in older people, so I was not worried. The final round was a year ago, when I was getting an honorable mention at the hospital where I worked. I got up to thank but I couldn't say a word. My general practitioner performed a series of memory tests in his office and then asked for a PET scan, which diagnoses the disease with $95 \%$ accuracy. I started to be medicated with Aricept, a competitive, reversible acetylcholinesterase inhibitor (an enzyme that hydrolyzes the neurotransmitter acetylcholine, found mainly at neuromuscular junctions and cholinergic cerebral synapses. This enzymatic activity ends the synaptic transmission). This medication has many side effects and I presented two of them: diarrhea and loss of appetite. My doctor insisted that I continue. The side effects disappeared and I started taking another medication, Namenda. In two months, I felt much better and today I almost returned to normal. It took us a long time to understand this disease since Alois Alzheimer, a German physician, established the earliest links in the early 20th century between dementia and the presence of plaques and tangles of unknown material. Today we know that this material is the accumulation of a protein called beta-amyloid that presents problems on folding, no longer presenting its native form. The main hypothesis for the mechanism of Alzheimer's disease is that this protein accumulates in brain cells due to low solubility, causing neuron degeneration. Today, there are some pharmaceuticals to clean that protein from the cells. However, amyloid plaques can only be detected in an autopsy, so they are only associated with people who have fully developed the disease.

\section{Patients from Infirmary 2}

At 12 years old, $1.60 \mathrm{~m}$ in height and $49 \mathrm{~kg}$ I thought I was fat and started to do a "basic" regime and exercise. At 13 years old I weighed $36 \mathrm{~kg}$ and still thought I was fat. I would do 1 to 2 hours of exercise $6 \mathrm{x}$ a week and I started to vomit and from time to time "attack" the refrigerator. With $32 \mathrm{~kg}$, my mother became desperate and discovered that I was vomiting. With $30 \mathrm{~kg}$, and very malnourished, a doctor wanted to hospitalize me due to the diagnosis of nervous' anorexia. However, I hid food in my pockets and vomited afterwards. Despite of being forbidden to exercise I woke up at dawn to do it. The doctor gave me a week to increase from $500 \mathrm{~g}$ to $1 \mathrm{~kg}$ otherwise I would be hospitalized. When I went to consult again, I had lost $200 \mathrm{~g}$. I had been hospitalized and started to say that I'd do a hunger-strike. The doctor gave me 4 days to increase $400 \mathrm{~g}$ and brought the catheter to my room showing what would happen if I did not start eating. I had no choice and I started to eat. It was 3 months and a half of suffering and I went back home at Easter. I didn't go out because I thought I was fat and I didn't want 
anyone to see me like that with $1.60 \mathrm{~m}$ and $56 \mathrm{~kg}$. I had a relapse $(1.60 \mathrm{~m}$ and 30 $\mathrm{kg}$ ) and I was hospitalized with a high fever, for which they gave me an antipyretic and restarted my food treatment.

\section{Patients from Infirmary 3}

The patient was admitted with precordial, constrictive pain started six hours before. The pain was of moderate intensity, precipitated during rest, without irradiation, not accompanied by nausea or sweating. Two days before, he presented a similar clinical picture, accompanied by upper airway congestion. The night before the care he also reported similar pain, accompanied by sweating and spontaneous remission. Personal Background: Hypertriglyceridemia, Always susceptible of having colds and flu. Family Background: Father died of heart problems not defined at age 60 years old. Paternal and maternal uncles with proven coronary artery disease. Denies diabetes mellitus and systemic arterial hypertension. Physical examination: BEG (Good General Condition), colored, hydrated, eupneic, acyanotic, anicteric and afebrile. He was discreetly anxious. Blood pressure of $140 \times 75 \mathrm{~mm} \mathrm{Hg}$ and $\mathrm{HR}$ of 70 beats per minute (normal), rhythmic. He did not show changes in the rest of the exam. The initial ECG revealed a sinus rhythm, a discreet ST elevation in D1, V3, V4, V5 and V6. The echocardiogram showed absence of akinetic areas and pericardial changes. Other normal indexes. Laboratory tests showed elevated and consistent myocardial necrosis (Creatin Kinase MB-0.4 $4.0 \mathrm{ng} / \mathrm{mL}$ and Troponin $(<1.0 \mathrm{ng} / \mathrm{mL}$ ) with Creatin Kinase MB $(55 \mathrm{ng} / \mathrm{mL})$ and troponin $(23 \mathrm{ng} / \mathrm{mL})$ The patient was diagnosed with acute myocardial infarction and was treated with beta-blockers and aspirin and, occasionally, diazepinic, and was discharged on 7th day. The Aspirin has been used as a preventive treatment for heart problems as it is a suicidal Cyclooxygenase inhibitor, which exists in the inflammatory process and in platelets. This enzyme catalyzes the formation of prostaglandins, which cause platelet aggregation.

\section{Patients from Infirmary 4}

At 18 years old I started practicing boxing where I got to do several fights and won the Brazilian amateur championship. I started other sports like bodybuilding and canoeing. We paddled in a Canadian-style canoe, when a friend told me that there'd be a Marathon Canoeing event on Lake Paranoa. Thus, I went to the race, but I could hardly sleep, since I had enrolled in the test of $12 \mathrm{~km}$, and I had never paddled that distance. It was given the start and I tried to follow the first competitor, but without any technique I could not print much speed. I ended up fainting and now I am hospitalized for a respiratory alkalosis that seems to be a nervous background, according to the doctors, due to my anxiety. The only treatment needed was to slow the breathing. If it had not worked, they'd make me breathe into a paper bag to increase the carbon dioxide content of the blood, said the doctor. 


\section{Supplementary Material}

At 14 years old, I began to practice canoeing, where I done various races and won the Brazilian amateur champion. I started other sports like bodybuilding and running. We ran as a team, it was when I heard from friends that will be an individual event. There I went to the test, I could hardly sleep, because I had enrolled in the test of $20 \mathrm{~km}$, and had never run that distance. It was given the start and I tried to follow the first placed, but without any technique I couldn't print much speed. I ended up fainting and now I'm hospitalized for a respiratory alkalosis that seems to be a nervous background, according to the doctors, due to my anxiety. The only treatment needed was to slow the breathing. If it hadn't worked, they'd make me breathe into a paper bag to increase the carbon dioxide content of the blood, that's the doctor told me.

At 11 years old, 1.67 tall and $52 \mathrm{~kg}$ I thought that I was fat and started to make a "basic" regime and exercise. At 13 years old I weighed $49 \mathrm{~kg}$ and still found myself as fat. I would do 1 to 2 hours of exercise $6 \mathrm{x}$ a week and I started to vomit and from time to time "attack the refrigerator". With $35 \mathrm{~kg}$, my mother got desperate and discovered that I was vomiting. With $32 \mathrm{~kg}$, and very malnourished, a doctor wanted to hospitalize me by the diagnosis of anorexia nervosa. I still hid food in my pockets and I vomited after. Forbidden I woke up at dawn to exercise. The doctor gave me a week to increase from $500 \mathrm{~g}$ to $1 \mathrm{~kg}$ otherwise I would stay at the hospital. When I went to consult again, I had been hospitalized and started to say that I was doing a hunger strike. The doctor gave me 4 days to increase $400 \mathrm{~g}$ and brought the probe to my room for showing what would happen if I didn't start eating. I had no choice and I started to eat. It was 3 months and a half of suffering and I went home at Easter. I didn't go out because I think that I was fat and I did not want anyone to see me like that with $1.68 \mathrm{~m}$ and $60 \mathrm{~kg}$. I had a relapse $(1.68 \mathrm{~m}$ and $34 \mathrm{~kg}$ ) and I was hospitalized again with a high fever, receiving an antipyretic and food supplementation.

I'm a retired teacher and I've Alzheimer's. Today, knowing that I've the disease, I was able to determine when it started 10 years ago when I was 76 years old. I began to forget names, but never physiognomy. These lapses are common in older people, so I don't worry. The final blow was a year ago, when I was getting an honorable mention in the school where I worked. I got up to thank but I couldn't say a word. My general practitioner performed a series of memory tests in his clinic and then asked for a PET scan, which diagnoses the disease with 95\% accuracy. I started taking Donezepil, a competitive reversible acetylcholinesterase inhibitor (an enzyme that hydrolyzes the neurotransmitter acetylcholine, found primarily at neuromuscular junctions and cholinergic brain synapses, where this enzymatic activity serves to shut down synaptic transmission). Use this medication has many side effects, I resented two of them: diarrhea and loss of appetite. My doctor insisted that I continue. The side effects disappeared and I started taking another medication, Namenda. In two months, I felt much better and today I almost returned to normal. It took us a long time to under- 
stand this disease since Alois Alzheimer, a German physician, established the earliest links in the early 20th century between dementia and the presence of plaques and tangles of unknown material. Today we know that this material is the accumulation of a protein called beta-amyloid that begins to present problems of folding, no longer presenting its native form. The main hypothesis for the mechanism of Alzheimer's disease is that this protein accumulates in brain cells due to low solubility, causing a degeneration of neurons. Today, there're some pharmaceuticals to clean that protein from the cells. However, amyloid plaques can only be detected at an autopsy, so they are only associated with people who have fully developed the disease.

The patient got into the First Service referring to precordial, constrictive pain started six hours before. The pain was of moderate intensity, precipitated during rest, without irradiation, either accompanied by nausea or sweating. Two days before, he presented a similar clinical condition, accompanied by upper airway congestion. The night before of the care the patient also reported similar pain, accompanied by sweating and spontaneous remission. Personal Background: Hypertriglyceridemia, the ease of having colds and flu. Family Background: Father died of heart problems not defined at age 60. His paternal's and maternal's uncles have coronary artery disease. Denies diabetes mellitus and systemic arterial hypertension. Physical examination: BEG (Good General Condition), colored, hydrated, eupneic, acyanotic, anicteric and afebrile. He was discreetly anxious. Blood pressure of $140 \times 75 \mathrm{~mm} \mathrm{Hg}$ and $\mathrm{HR}$ of 70 beats per minute (normal), rhythmic. It did not show changes in the rest of the exam. The initial ECG revealed a sinus rhythm, a discreet ST elevation in D1, V3, V4, V5 and V6. The echocardiogram showed absence of akinetic areas and pericardial changes. Other normal indexes. Laboratory tests showed elevated and consistent myocardial necrosis (Creatin Kinase MB-0.4 $4.0 \mathrm{ng} / \mathrm{mL}$ and Troponin $(<1.0 \mathrm{ng} / \mathrm{mL}$ ) with Creatin Kinase MB (55 ng/mL) and troponin $(23 \mathrm{ng} / \mathrm{mL})$. The patient was treated with beta-blockers and aspirin and, occasionally, diazepinic and was discharged on the 7th day. Aspirin has been used as a preventive treatment for heart problems, being a suicide inhibitor of cyclooxygenase that exists in the inflammatory process and in platelets, in which the enzyme catalyzes the formation of prostaglandins, which cause platelet aggregation. 